\title{
An Ecofeminist Reading of Han Kang's The Vegetarian
}

\author{
Shilpa Bright
}

Student

Master of Art. English Language and Literature

Bishop Kurialachery College

Mahatma Gandhi University

Kottayam, Kerala, India

shilpabright1998@gmail.com

Abstract

Ecofeminism depicts the movements and philosophies that establish a close relationship between women and nature. It is also an academic movement that sees a critical connection between the domination of nature and the exploitation of women. The term 'Ecofeminism' was coined by the French writer Francoise d'Eaubonne. This term intersects the two critical perspectives- ecology and feminism. Ecofeminist theory asserts that a feminist perspective of ecology does not place women in the dominant position. This theory can be used to explore the connection between women and nature in culture, religion, literature and thus address and bring out the parallels between the oppressions of nature and the oppressions of women. Using gender as an important factor, ecofeminism examines the conditions that cause and perpetuates the subordination of both women and nature. This analysis includes seeing men as the curators of culture and women as the curators of nature, and also how men dominate women and humans dominate nature. This paper titled, 'An Ecofeminist Reading of Han Kang's The Vegetarian' discusses the term ecofeminism and how this theory can be analysed and applied in this book written by Han Kang, a South Korean writer who won the Man Booker International prize for fiction in 2016 for this particular book. The book is about a 
home-maker whose decision to stop eating meat after a deadly nightmare about human cruelty leads to various problems in her personal life. This paper mainly tries to bring out how women and nature are oppressed by the patriarchy and how both are showing resistance toward this dominance. It investigates how man colonizes nature and as well as women. There are various other books that can be analysed under this feminist theory but this book in a way different as the main protagonist of this book sees vegetarianism as a way of not causing any harm on anything, but asserting her identity and freedom in patriarchal society. Thus this paper brings of the various ecofeminist aspects that can be analysed in this book through the various contexts related to the protagonist. Keywords: Eco-Feminism, Nature, Patriarchy, Vegetarianism, Exploitation.

Ecofeminism depicts the movements and philosophies that establish a close relationship between women and nature. It is also an academic movement that sees critical connection between the domination of nature and the exploitation of women. The term 'Ecofeminism' was coined by a French writer Francoise d'Eaubonne in 1974 in her book Feminism or Death (1980). The term ecofeminism intersects the two critical perspectivesecology and feminism. Ecofeminist theory asserts that a feminist perspective of ecology does not place women in the dominant position. Ecofeminism uses gender as an important factor to examine the condition that causes and perpetuates the subordination of both women and nature. Nature is man's must companion. It provides comfort to all. It is the basic source of anything and everything in this society. Women are closely associated with nature and it is feminized, as it possesses the qualities of women. The journey of ecofeminism links the philosophy of feminism with ecology. This philosophy interconnects and brings out the abuse and dominance of women with that of the environment. Ecofeminist argues that women are better than men to relate with nature and they are in fact closer to nature. Women, through their alteration in their body like ovulation, mensuration, pregnancy, giving birth, breast 
feeding and much more are very much closer to Nature and Mother Earth. There are many who come up and voice for ecofeminism. Some of them are Rosemary Radford Ruether, Vandana Shiva, Andy Smith, Alice Walker, Susan Griffin and Karen J. Warren. Rosemary Radford Ruether, in one of her ecofeminist books, New Women, New Earth: Sexist Ideologies and Human Liberation, states:

Women must see that there can be no liberation for them and no solution to the ecological crisis within a society, whose fundamental model of relationships continues to be one of domination. They must unite the demands of the women's movement with those of the ecological movement to environ a radical reshaping of the basis socio-economic relations and the underlying values of the society (210).

Ecofeminism is used as a feminist as well as an environmental theory. It comprises a variety of ideas. Ecofeminism describes using a particular lens of environmental and social problem to get feminism in a new light. Its main principal or idea is to address both social and environmental issues together. The feministic movement that arouses in South Korea is quite recent compared to that of the first wave and second wave of feminism in the Western World. The sufferings faced by women in South Korea were included in the Article II of the National Constitution in 1948. There was a gradual increase in the feminist groups in South Korea. Han Kang is a South Korean writer who won the Man Booker International prize for fiction in 2016 for The Vegetarian. She is the first Korean to be nominated for the Man Booker Prize Award. The Vegetarian, originally published in South Korea in 2007 and inspired by the author's short story The Fruit of My Women, was the first of Han's work to be made into a feature film. The novel is one of her first books to be translated into English. The novel deals with the decision of a woman to stop eating meat and the consequences she had to face in her life. The novel originally written in South Korean is translated into English by 
Deborah Smith. TheVegetarian is a three part novella first published in 2007. The novel is set in modern day Seoul and tells the story of Yeong-hye, a part time graphic artist and homemaker, whose decision to stop eating meat after a bloody, nightmarish dream about human cruelty leads to devastating consequences in her personal life. The story is told in three parts: The Vegetarian, Mongolian Mark, and Flaming Trees. The first part is narrated by Yeonghye's husband Mr. Cheong. The second part is narrated from the point of view of Yeonghye's brother-in-law, a video artist and the third part remains in a third person narrative and mostly focuses on her sister, In-Hye. The final chapter takes place three years after the opening of the novel. By then, Yeong-hye is now in a psychiatric hospital, where she refuses all food and self imposes starvation. She gradually isolates herself from everything, ignores all the societal norms that requires suppression and then starts identifying herself as a plant rather than a human being and ends up eating nothing at all.

Han Kang's exasperating novel, The Vegetarian, clearly exhibits that women are biologically closer to nature. This novella mainly deals with desire, shame and empathy reflected by the characters faltering attempts to understand the people around them. As the title suggests, the book is not wholly about the philosophy of vegetarianism and the associated diets but rather only mentions about these in some parts of the book. The book mildly stresses the idea of a non-vegetarian person deciding to practise vegetarianism. This paper shows how women are oppressed by the patriarchy and how both are showing resistance towards this dominance. It investigates man's colonization of nature and woman's body. The main character of this novel, Yeong-Hye, sees vegetarianism as a way of not inflicting harm on anything, but asserting her identity and freedom in a patriarchal society. The novel is all about Yeong-Hye's decision to stop eating meat and the devastating consequences that she had to face in her personal life. The opening part of the novel is narrated by the character's husband, the second part is narrated through a third person which 
is her brother-in-law, and the final part is also a third person narrative where her sister is the narrator.

According to her husband Cheong, Yeong-hye is 'completely unremarkable in every way' (8), until she woke up one morning from a nightmare and decided not to eat meat anymore. All her family members are not happy about her decision of switching into vegetarianism and they continuously compelled her to consume meat. After a long silence she spoke up: 'I won't eat it'. Her voice was so firm and clear. It was almost like a rebellion against the male supremacy and hence her family was not ready to leave it right away like this.

Holding a steaming paper cup in one hand, my mother-in-law grasped my wife's hand in the other. 'This...' Her eyes welled with tears. 'Take this. Ah' loot at your face'. My wife obediently took the paper cup. 'It's herbal medicine. They say it strengthens the body. Why, in the old days, back before your marriage, we had the very same medicine made up for you, remember?'(46)

All the attempts made by her family turn futile and thus they are frustrated and angry at her because she isn't ready to explain to them the reason behind her transformation. The only response is 'I had a dream'. (8)

Across the frozen ravine, a red barn like building. Straw matting flapping limp across the door. Roll it up and I'm inside, it's inside. A long bamboo stick strung with great blood - red gashes of meat, blood still dropping down, try to push pat but the meat, there's no end to the meat and no exit. Blood in my mouth, blood soaked clothes sucked on my skin... In that barn, what had I done? Pushed that red raw mass into my mouth, felt in squish against my gums, the roof of my mouth, slick with crimson blood. Chewing on something 
that felt so real... Familiar and yet not... that vivid, strange, horribly uncanny feeling. (12)

It was the nightmare that she saw which included much blood soaked images that felt so real that lead to her transformation into a vegetarian. The image in her dream is of a dog that was killed by her father and was eaten by her whole family including herself, symbolising the sense of guilt about the lives taken for others sustainability. She believes that eating meat symbolizes human violence, the violence of this world and she chooses pure vegetarianism as a way of excluding herself from that violence. The novel is a critique of socially prescribed gender roles and the politics of breaking free from hetero normative domesticity. For instance, at the very start of the novel, the protagonist's husband narrates the 'problem' of his wife's refusal to wear a bra and his attempts to constrain, at least sartorially, her body:

I would have preferred her to go around wearing one that was thickly padded. So that I could save face in front of my acquaintances... Even in the summer, when I managed to persuade her to wear one for a while, she'd have it unhooked barely a minute after leaving the house. The undone hook would be clearly visible under her thin, light coloured tops, but she wasn't remotely concerned. I tried reproaching her, lecturing her to payer up with a vest instead of a bra in that sultry heat. She couldn't stand wearing a bra because of the way it squeezed her breasts, and that I'd never worn one myself so I couldn't understand how constructing it felt. Nevertheless, considering I knew foe a fact that there were plenty of other women who, unlike her, didn't have anything particularly against bras, I began to have doubts about this hypersensitivity of hers. (5) 
In the novel, at the end of the first part, The Vegetarian, after attempting to commit suicide, Yeong-Hye was sent to the mental hospital, where she is touched by a wounded bird. The second section, Mongolian Mark, relays the consequences of Yeong-hye's defiance through another bodily symbol: a birthmark on her buttocks. She is hospitalized after attempting to commit suicide with a fruit knife, and subsequently lives with her sister and brother-in-law. She always maintained a connection with nature and all her actions resembled to it. The following incident is an evident for this.

She would occupy herself in picking up the dried leaves that had fallen from the flower pots and crumbling them into a fine powder, or in stretching out the palm of her hand to cast shadows over to the floor. (69)

Brother-in-law becomes fixated with "almost inhuman patience" of his wife's vegetarian sister. It is her brother-in-law that projects on her a vegetal image since they first met, when he saw her "like a tree that grows in the wilderness, denuded and solitary" (64). Then he actively displays his psyche on her body:

Half opened buds, red and orange, bloomed splendidly on her shoulders and back, and slender stems twined down her side. When he reached the hump of her right buttock he painted an orange flower in full bloom, with a thick, vivid yellow pistil protruding from its centre. He left the left buttock, the one with the Mongolian Mark, undecorated. Instead, he just used a large green, fainter than the mark itself, so that the latter stood out like the pale shadow of a flower. (84)

It is the first time that we see her happy and feeling at home, in her skin: when it becomes not her skin, in fact but something else. Her brother-in-law recognizes this in a stirring moment, 'this was the body of a beautiful young woman, conventionally an object of 
desire, and yet it was a body from which all desire had been eliminated... that her body represented'. (85)

His vision is internalized by Yeong-Hye since she values it as a solution to her problem: becoming a plant would take her out of violence circle not only in her actions but also in her dreams. Yeong-Hye now starts identifying herself as a plant rather than a human. She possesses the qualities of both plant and human and she denies her identity as a woman.

Her calm acceptance of all these things made her seem to him something sacred. Whether human, animal or plant, she could not be called a 'person', but then she wasn't exactly some feral creature either- more like a mysterious being with qualities of both. (88)

Women along with the plant are disrespected and deserve respect. An important idea in ecofeminism is the contradiction between matriarchal earth and masculine society. Here protagonist tries to become a plant, she denies respect as a woman and tries to retrieve her freedom by identifying herself as a plant.

Her skin was pale and green. Her body prone in front of him, like a leaf that had just fallen from the branch, only barely begun to wither, the Mongolian Mark was gone; instead her whole body was covered evenly with that pale wash of green. (96)

By observing the protagonist's transformation from a meat eater to a vegetarian, from a woman to a plant, which is followed by a series of subsequent changes in a male dominated patriarchal society; Yeong-Hye always has an affinity towards nature. Her brother-in-law takes this as an advantage to seduce her.

He watched as she turned her back on him and walked decisively over to the door. As she scrunched her feet into her trainers he shouted over to her: 'If...' 
He couldn't keep a shrill note from his voice. 'If I painted flowers on myself, would you do it then?' (107)

The undesired body becomes an object of desire by the switch of the viewer (the same body is viewed just as a "skeletal frame of an invalid" by her husband but whereas the same body is seen as an appealing feature by her brother-in-law). This transformation of the body according to this point of view displays its fragility and its ability to mutate. This readily mutant body aims to spit out the meat within: by not consuming it, by losing weight, by covering it with flowers (a sequence of the process of becoming a plant).Yeong-hye's struggle of becoming a tree causes tremendous terror as it designates a realm which can never be explained. The more she tries to become like a plant like being, the more her voice is recognized as that of a wild beast than a human.

The association of women with plants have a very long history, with the resemblance of a woman's beauty to a flower's abundantly nurturing countless forms of literary and artistic expressions throughout the centuries. Metaphors, symbols, allegories have traditionally provided the way for displaying the flow of forms between vegetarian and people and texts account for cases of full transformations of the latter into plants. Probably one of the most renowned literary grounds for becoming of people as plants is Ovid's Metamorphoses, which includes more than twenty episodes dealing about it in figures such as Myrrha, Narcissus, Daphne and much more. Daphne, the daughter of earth and the river Ladon (according to Arcadian version) or of the river Peneus (according to Thessalian version), which is the one retrieved by Ovid, awoke Apollo's love but would not let herself be seduced by him, preferring a perpetual maidenhood. When Apollo finally pursued her in order to impose his love, she asked for help and this consisted in her transformation into a laurel tree, escaping this way the God's lust. Apollo made a crown out her laurel leaves that 
he would wear from then on. During her transformation into a tree, Daphne's body was covered with bark, hair turned into leaves, and she implanted in the earth.

This paper rather focuses on the particulars of Yeong-Hye's transformation into a plant and recalls Daphne as the traditional figure of comparison when it comes to the womenplant association. First of all, Yeong-Hye does not actually become a plant like Daphne did. The novel maintains a level of distinction between the real and the imaginary. The thread of this novel is taken from a short story by Han Kang's titled The Fruit of My Woman, in which this metamorphosis does occur, as the character effectively becomes a plant and her husband puts her in a pot and takes care of something he did not do when she was a human being. The details like "the pale blue bruises the size of new-born's foot..." (3) From the short story, The Fruit of My Woman, evolved into the "blue petal-like birth mark" on Yeong-Hye's hip that can be seen in the novel The Vegetarian. The women in The Fruit of My Woman does not make the decision to become a plant, it is something that happened to her and over which she had no control. Daphne didn't make this decision either: she just asked for a way to escape. Apollo at last suggested herself to turn herself into a plant. But in the novel The Vegetarian, Yeong-Hye wants to transform herself into a plant and willingly takes up the starvation and isolation. She stops eating and only asks for water. "I need to water my body, I don't need this kind of food, sister, I need water" (148). Yeong-Hye eventually avoids consumption not only of meat, but also of everything except sunshine. "I don't need to eat, not now, I can live without it. All I need is sunlight" (154). In the second part of the novel The Vegetarian, the body of the protagonist is changed into a blooming tree and flowered sap emerge from her naked body:

I was standing on my head... Leaves were growing from my body, and roots were sprouting from my hands... so I dug down into the earth. On and on... I 
wanted flowers to bloom from my crotch so I spread my legs: I spread them wide... (148)

Her sister starts feeling sympathy for her and starts protecting her from the harsh treatments of the hospital. Towards the third part of the novel, we can see that the story itself is narrated by her sister In-Hye where she describes how Yeong-Hye's vegetarianism has grown to a severe level of insanity. Yeong-Hye, in spite of receiving all the severe treatments, sticks on to the belief that being a plant is the best way to avoid human violence by no longer being a human being. At the end she happily declares herself to be no longer an animal. In the last chapter, Kang didn't want to describe the death of Yeong-Hye but instead she ended the book with a final scene, where her sister looks out of the ambulance window with a protesting gaze. The sad truth is also symbolized to the readers through the dull climatic condition that prevailed then.

Black rain, black woods, the pale patient's uniform, soaked through. Wet hair. Black mountain slope. Yeong-hye, an inchoate mass forms of darkness and water, standing tall like a ghost. (127)

According to the author, she does not care about her own happiness. She is eager to return to the state of innocence, by buying back the freedom of her soul at the cost of her physical existence. All signs point to her wanting to become something that isn't nourished through violence towards other living beings: sitting by the fountain, soaking in the sun, shedding her clothing and walking around naked as often as she can, only to stand still among the tree as if trying to join them. She defies humans not only by becoming vegetarian, but by trying to be a vegetation itself. The novel is more of a criticism of the society which surrounds Yeong-hye than her as a woman and there lies the beauty of the novel. As the story moves forward each character in the novel is forced to re-examine their own lives. In Kang's other work, The Fruit of My Woman, the unnamed wife gets literally transferred into a plant 
whereas in The Vegetarian, the main protagonist Yeong-hye doesn't transform totally into a plant. The author wrote The Fruit of My Woman as a direct precursor to the 2015 novel, The Vegetarian. In both the works, a married couple in their early thirties finds their uneventful lives turned upside down, when the woman starts to undergo change. If in the short story the transformation is an actual fact, in the novel it is just a supernatural event that the protagonist badly desires for. Yeong-hye and the unnamed wife opposes human brutality and no longer wants to remain human beings. Both of the women characters transform themselves into plants to show this strong disagreement to human violence and patriarchal norms. They represent all women as well as the Mother Earth who are being exploited by men. Their act of embracing nature shows their clear refusal of the existing conventions set by the so called 'patriarchy'.

Women were seen as being domestic, moral, pure, gentle, graceful, simple and beautiful. This perspective was according to nature and separated the spheres. Men were seen as hardworking, industrial, independent and assertive whereas women the other way round. Therefore nature was seen as the embodiment of all the characteristics that women possess. The violence of nature has been used to explain the violence against women. Both the environment and women have been viewed as exploitable resources that are significantly undervalued. Therefore, destruction of the environment results in elimination of women's method for survival. There are many works which deal with the relation between women and nature. South Korean writer Han Kang's Man Booker International Prize winning novel The Vegetarian can be given an important place in the history of ecofeminism. The novel is beautifully written, with an excellent translation from Deborah Smith (her first major work). The novel can be seen as a social protest, and this protest is against the existence itself.

The Vegetarian is primarily an ecofeminist novel. Firstly, the ecofeminist aspects are shown through the protagonist's relationship with the male characters in her life. Then in 
Yeong-hye and Mr. Cheong's marriage, man's super power over woman and woman's loss of identity and suppressed state are clearly illustrated. Secondly, Yeong-hye's story is the alienation from the patriarchal world until she finds a world of her own in nature. She not only lacks all social contacts, but also feels isolated from her family. She reacts against the patriarchy. Her strong disapproval can be seen in the scene where her father forces her to eat meat and she finally rejects him. She stands up against human brutality and in turn transform herself in to a plant. However her journey turns out to be a spiritual one for her, in which she realizes that she belongs to nature and in fact, towards the end she becomes one with the nature. 


\section{Works Cited}

Smith, Deborah, translator. The Vegetarianism. By Author Han Kang,Granta Publications, 2015.

The Fruit of My Woman, a short story written by Han Kang, Granta Publications.

Metamorphoses, an epic poem by Ovid. 